\title{
1 The Impact of Phytohormones on Virus Infection and Disease
}

2 Tamara D. Collum ${ }^{1}$ and James N. Culver ${ }^{2,3}$

$3 \quad{ }^{1}$ Department of Cell Biology and Molecular Genetics

$4 \quad$ 2nstitute for Bioscience and Biotechnology Research

$5 \quad{ }^{3}$ Department of Plant Science and Landscape Architecture

$6 \quad$ University of Maryland, College Park, MD 20742, USA

7

8 Corresponding Author: James N. Culver

$9 \quad$ PSLA \& IBBR

10 University of Maryland, College Park, MD 20742

11 Ph: 405-2912, Fax (301) 314-9075

12 Email: jculver@umd.edu

13

\section{Abstract}

Phytohormones play a critical role in nearly every aspect of plant biology, including

16 development and pathogen defense. During virus infection disruption of the plant's normal

17 developmental physiology has often been associated with alterations in phytohormone 18 accumulation and signaling. Only recently has evidence emerged describing mechanistically

19 how viruses modulate phytohormone levels and the impact these modulations have on plant 
1 physiology and virus biology. From these studies there is an emerging theme of virus directed

2 manipulation of plant hormone responses to disarm defense responses and reprogram the cellular

3 environment to enhance replication and spread. In this review we examine the impact viruses

4 have on plant hormone systems and the effects of this phytohormone manipulation on virus

5 biology.

\section{Introduction}

7 Viruses utilize a variety of strategies to reprogram their host's cellularenvironment to one

8 that is more conducive to replication and spread.As a consequence virusinfections can directly or

9 indirectly disrupt phytohormone accumulation and signaling pathways. Within plants there are an

10 array of plant hormone pathways that contribute to nearly all aspects of plant physiology

11 including growth, development and reproduction [1].Salicylic acid (SA), jasmonic acid (JA) and

12 ethylene (Et) are primarily involved in defense mechanisms[2]. Auxin (Aux), gibberellins (GA)

13 cytokinins (CK), brassinosteroids (BR) and abscisic acid (ABA) also contribute to defense but

14 play key roles in plant development and physiological processes [3,4]. In addition, there are

15 extensive interactions or "cross-talk" between the different phytohormone pathways, providing a

16 means for the plant to finely regulate responses to environmental cues or pathogen

17 attack[3,5,6]. Here we discuss the role of phytohormones in the development of disease

18 symptoms, the modulation of host defensesand enhancement of virus replication and movement.

19 We focus primarily on specific virus-host interactions that have been linked to alterations in

20 phytohormone synthesis and signaling and the role these interactions play in infection and 21 disease.

\section{Symptom development}


2 curling and chlorosis. These types of symptoms have long been associated with disruptions in

3 plant hormone production, accumulationand sensing[7,8].Yet despite these associationsour

4 understandingof the viral components and interactions that affectphytohormone pathwaysand

5 their role in symptom development is limited. Recently several interactions between viral and

6 host components involved in phytohormone pathwayshave been identified and linked to

7 symptom development. These interactions provide the first mechanistic explanation for how

8 viruses modulate phytohormone regulatory systems within their hosts and how those

9 modulations lead to symptom development.One phytohormone system that is directly disrupted

10 by viral components is Aux. Disruption of Aux signaling has been linked to developmental

11 phenotypes with Aux biosynthesis or signaling mutants resembling viral disease symptoms such

12 as stunting, leaf curling, and loss of apical dominance [9]. The Tobacco mosaic virus(TMV)126

$13 \mathrm{kDa}$ replication protein has been shown to disrupt Aux signaling via an interaction with select

14 Aux/IAA family members[10,11]. These Aux/IAA proteins function as negative regulators of

15 Aux responsive transcription factors (ARF) and controltheir ability to modulate genesinvolved in

16 a range of plant processes [12]. Interaction with the TMV $126 \mathrm{kDa}$ protein disrupts the nuclear

17 localization of interacting Aux/IAA proteinsand correlates with the development of leaf curling

18 and developmental disease symptoms. In contrast, a mutant, TMV-V1087I or related virus,

19 Tobacco mild green mosaic virus, do not interact with these Aux/IAA family members and

20 produce attenuated disease symptoms even though these viruses replicate to wild-type TMV

21 levels [11].Thusthe TMV - Aux/IAA interaction appears to be an important determinant in the

22 development of disease. 
The activity of viral silencing suppressors has also been linked to alterations in Aux

2 signaling and the development of disease symptoms. Specifically, transgenic Arabidopsis plants constitutively expressing theTurnip mosaic virus (TuMV)silencing suppressorHC-Pro display

4 leaf developmental abnormalities similar to those that occur during virus infection[13].

5 Overexpression of HC-Pro was found to increase accumulations of several miRNAs, including

6 ones targeting Aux responsive transcription factors. Furthermore, increased levels of these

7 miRNAs corresponded with enhanced cleavage of their target mRNAs[13]. The authors

8 concludethat expression of viral suppressor proteins interferes with miRNA regulated pathways

9 including those under the control of Aux and that disruption of these pathways accounts for many of thedevelopmental symptoms induced during virus infection.

Disruption of the GA biosynthesis pathway has also been linked to viral disease

12 symptoms. GA is involved in cell division and elongation.Rice dwarf virus (RDV) induces

13 stunting and leaf darkening, symptoms that are characteristic of GA-deficient rice mutants. An

14 interaction between the RDV outer capsid P2 protein and the rice ent-kaurene oxidase has been 15 identified[14]. Ent-kaurene oxidases are key components in the synthesis of GA and have been 16 linked to dwarfing in rice[15,16]. Treatments of RDV infected plants with exogenous GA 17 restored the non-dwarf phenotype but not treatments with Aux [14].It was speculated that the 18 virus directed disruption of ent-kaurene oxidase activity was responsible for symptom 19 development but couldalso potentially interfere with the synthesis of antimicrobial phytoalexins, 20 leaving the plant more susceptible to infection.

Another example of a viral component linked to symptom development is the P6 protein 22 of Cauliflower mosaic virus (CaMV). P6 is a multifunctional viral protein involved in virus 23 replication, movement and suppression of RNAi[17,18]. Transgene expression of P6 induces 
1 stunting, chlorosis and vein banding [19]. P6 expression has been shown to interfere in the

2 ethylene response pathway as P6 transgenic Arabidopsis plants display an ethylene-insensitive

3 phenotype [20,21]. It was suggested that P6 may interfere with ethylene signaling leading to the

4 observed symptoms [21]. However, a direct interaction between P6 and a component of the

5 ethylene pathway has not been identified.

\section{Defense Responses}

7

8

SA is a key virus defense phytohormone involved in $\mathrm{R}$ gene mediated resistance, systemic acquired resistance (SAR) and basal defense processes[22-25].Activation of SA biosynthesis and signaling can lead to the accumulation of reactive oxygen species, pathogenesis-related (PR) proteins, callose deposition and induction of the hypersensitive response [22,23,26,27]. SA is also required for SARactivation in tissues distal from the site of infection[24]. SA and JA/ ET mediated defense pathways are generally antagonistic, with SA largely responsible for defense against biotrophic pathogens such as viruses and JA/ET largely responsible for defense against necrotrophic pathogens and insects[28-30]. However, examples of synergism between these pathways do exist [31-33].

In many studies depletion of endogenous SA or disruption of SA signaling leads to an impairment of defense response and susceptibility to viral infections [34-38]. For example, reducing the accumulation of SA through the use of a salicylate hydrolase (NahG) transgene negates resistance conferred by the potato $N y-1 \mathrm{R}$ gene against Potato virus $\mathrm{Y}$ [39].Thus inhibition of SA synthesis or SA dependent defenses is one strategy viruses may use to enhance infection. Virus interactions that impact the SA pathway include the TMV replication protein, which was found to target the proteasome degradation of a NAC domain transcription factor, 
1 ATAF2, involved in the regulation of host basal defenses [40]. ATAF2 knockout or repressor

2 lines displayed reduced levels of the SA marker gene PR1 when treated with SA. In addition,

3 PR1isnot induced upon SA treatment of systemically infected leaf tissues, indicating that host

4 defense responses become attenuated as TMV moves systemic. These findings suggest that

5 TMV targeted degradation of ATAF2 is involved in the suppression of SA mediated defenses.

6 In another example, the CaMV P6 protein has been shown to inhibit SA dependent

7 defenses by altering the expression and localization of the SA receptor NPR1[41,42]. Plants

8 expressing P6 display the miss-localization of an inactive form of NPR1 to the nucleus,

9 effectively disruptingSA signaling [42]. As a result plants expressing P6 are more susceptible to

10 SA sensitive pathogens but more resistant to JA sensitive pathogens [42].Additionally, a recent

11 study with TMV-Cg, crucifer strain, has shown the virus coat protein (CgCP)can also suppress

12 SA signaling by stabilizing DELLA proteins without altering SA or JA levels[43]. DELLA

13 proteins are negative regulators of GA signaling andhave been shown to repress SA defense

14 responses, possibly by modulating the antagonistic cross-talk between SA and JA pathways

15 [3,44].In addition, CgCP expression also reduces plant growth and delays the timing of floral transition, potentially linking this interaction to symptom development.

JA- SA antagonism appears to be a recurring factor in mediating virus defense processes. In $N$ gene resistant tobacco, exogenously applied methyl jasmonate reduced resistance to TMV 19 and conferred systemic viral movement [45]. Additionally, silencing of the JA receptor COI1 ora

20 JA biosynthetic enzyme,allene oxide synthase,resulted in increased SA accumulation and 21 reduced TMV accumulations in $N$ gene tobacco[45].Antagonistic interactions between SA and 22 JA signaling have also been implicated in defense gene expression and the activation of $R C Y 1$ 
1 resistance to Cucumber mosaic viruswhere a mutant allele of COI1, the JA receptor, restored

2 resistance in plants blocked in SA accumulation [35].Thus, antagonism between JA and SA

3 pathways represents an important mechanism in regulating $\mathrm{R}$ gene mediated resistance to these

4 viruses.However, increased JA accumulation is not always favorable for viral infection.

5 Endogenous JA levels have been reported to increase in incompatible plant-virus interactions in

6 tobacco and potato [46,47]. Additionally, exogenous application of JA disrupts geminivirus

7 infection [48]. Furthermore, the geminivirus C2 protein has been found to interact with the

8 catalytic subunit of the COP9 signalosome, compromising SCF ubiquitin ligase activity and

9 altering its ability to regulate JA activity.C2 targeting of SCF ubiquinationthus provides a 10 mechanism for this virus to modulate host resistance.

Phytohormones also appear to modulatethe general virus defense mechanism of RNA

12 silencing.Plants that contain mutations in RNA silencing pathway components including HEN1,

13 DCL1 and AGO1 are hypersensitive to ABA [49-51], while increased AGO1 levels lead to ABA

14 hyposensitivity [50,51].Additionally, miR168 which regulates AGO1 contains ABA-responsive

15 elements in its promoter region and is up regulated by ABA[51].There is also evidence for cross-

16 talk between SA and silencing defense pathways[52-55]. It was found that plants expressing

$17 N a h G$, for reduced accumulations of SA,produce lower levels of siRNAs when infected with

18 Plum pox virus (PPV).Furthermore, overexpression ofthe potyvirus silencing suppressor protein

19 HC-Pro reduced SA-mediated defenses against PPV[53]. Combined these findings suggest a

20 strong connection between virus defense responses and phytohormone signaling.

\section{Virus Replication}


Only recently has evidence emerged linking specific phytohormone systems directly to

2

virus replication. In one system SA was shown to inhibit the replication of Tomato busy stunt virus (TBSV) by competitively binding cytosolic Glyceraldehyde 3-phosphate dehydrogenase (GAPDH) [56]. Cytosolic GAPDH binds the negative RNA strand of TBSV and is required for replication[57,58]. When SA accumulates it can directly bind to GAPDH, preventing its interaction with virus RNA andleading to suppression of TBSV replication[56].In another system, a mutation in the ABA biosynthesis gene $A B A 2$ resulted in decreased Bamboo mosaic virus titers and a dramatic reduction of negative sense virus RNA[59]. Similarly, Cucumber mosaic virus (CMV) also failed to replicate in the aba2-1 mutant. The authors propose the product of $A B A 2$ may be an essential component of the virus replication or translation complexes or that ABA2 negatively regulates host defense responses. Based on these findings it is clear phytohormones and their associated components can directly impact virus replication.

\section{Movement}

The movement of viruses from cell-to-cell as well as into the vascular phloem occurs via intercellular plasmodesmata (PD) connections. Mounting evidence indicates that several phytohormones play a role in regulating PD connections. For example, ABA can limit virus spread through inhibition of $\beta$-1,3-glucanase, which degrades callose[60-62]. Deposition of callose at PD is known to decrease viral cell-to-cell movement [61,63,64]. Furthermore, exogenous application of ABA has been shown to increase plant resistance to viruses such as TMV and Tobacco necrosis virus by limiting virus movement [65,66].SA is another phytohormone linked toPD closure. Specifically, exogenous application of SA results in callose deposition within PD and reduced intercellular movement of a fluorescent marker dye [27]. This SA mediated PD closure requires the SA signaling pathway as well as a regulator of PD gating, 
1 PDLP5[67].SA has also been tied to the inhibition of virus movement and replication via a

2 process linked to the mitochondrial alternative oxidase pathway (AOX) [38,68]. Specifically, 3 inhibition of AOX functions to counter SA induced resistance against TMV, PVX and CMV. It

4 would be interesting to determine if AOX can contributeto the regulation of PD.Recently, we 5 determined that TMV disrupts the nuclear localization of select Aux/IAA genes that are

6 specifically expressed in phloem (unpublished data). The disruption of these vascular specific

7 IAA regulatory proteins was shown to correlate with the ability of the virus to load into the

8 phloem and move systemically.Thus, TMV appears to target the Aux signaling pathway as a

9 means to enhance its ability to spread systemically and cause disease.

The plant to plant movement of viruses via their insect vectors represents another aspect

11 of virus biology impacted by phytohormones. In particular, JA, the primary hormone involved

12 in plant insect defenses appears to be a key target in vector transmission. For example, Tomato

13 spotted wilt virus (TSWV) is vectored by the western flower thrip, which prefers to feed on

14 infected tissues[69]. Plants infected with TSWV have increased SA levels and decreased levels

15 of JA[29,69]. However, it remains to be determined if TSWV directly targets these pathways

16 inorder to enhance insect transmission. In another example, the $2 \mathrm{~b}$ silencing suppressor from

17 CMVwas found to interfere in the JA signaling pathway as a means to promote its own

18 transmission by its vectorMyzuspersicae. CMV infected plants or transgenic plants expressing 2b

19 display reduced levels of JAsignaling[70]. In addition, aphid survival increases on tobacco

20 infected with CMV but decreases on tobacco plants infected with CMV strain lacking 2b

21 [71].Finally, NIa-Pro (Nuclear Inclusion - Protease domain)fromTuMVhas been shown to

22 alterethylene responses, suppressing aphid-induced callosedefenses.NIa-Pro is highly conserved 
1 among Potyviruses and the authors propose this interaction could represent a conserved

2 mechanism for increasing aphid transmission of this important group of viruses[72].

\section{Conclusion}

From these studies it is clear that phytohormones play a significant role in many aspects

5 of virus infection and disease. Alterations in phytohormone levels have been repeatedly linked

6 to changes in virus accumulation. Furthermore, in a few systems we are beginning to understand

7 the molecular mechanism whereby viruses target and modulate plant hormone synthesis and

8 sensing systems to avoid host defenses and enhance their own infection and movement

9 (summarized in Table 1). It is also becoming increasingly clear that cross-talk between

10 phytohormonepathways is essential to the regulation of virus defense responses as well as a

11 target for viruses to exploit during infection (summarized in Figure 1). However, despite these

12 advances we still lack specific information on the phytohormone regulated genes and pathways

13 that directly impact virus biology. What Aux regulated genes are involved in symptom

14 development or what SA mediated processes directly impact virus accumulation are just a few of

15 the questions that when answered will provide a greater understanding of the interactions

16 between viruses and their plant hosts.

17 Acknowledgments: This work was supported in part by grants from USDA National Research 18 Initiative Competitive Grants (2015-67013-23004) and NSF (ISO-1120044). T.D.C. was 19 additionally supported by NIH Institutional Training grant 5T32AI051967 awarded to the 20 University of Maryland. 
1. Santner A, Estelle M: Recent advances and emerging trends in plant hormone signalling. Nature 2009, 459:1071-1078.

*2. Derksen H, Rampitsch C, Daayf F: Signaling cross-talk in plant disease resistance. Plant Sci2013, 207:79-87.

A recent review that describes the extensive cross-talk between phytohormone pathways that contributes to plant defense against pathogens.

3. Robert-Seilaniantz A, Grant M, Jones JD: Hormone crosstalk in plant disease and defense: more than just jasmonate-salicylate antagonism. Annu Rev Phytopathol2011, 49:317343.

4. Durbak A, Yao H, McSteen P: Hormone signaling in plant development. Curr OpinPlant Biol2012, 15:92-96.

5. Depuydt S, Hardtke CS: Hormone signalling crosstalk in plant growth regulation. Curr Biol2011, 21:R365-R373.

6. Song S, Qi T, Wasternack C, Xie D: Jasmonate signaling and crosstalk with gibberellin and ethylene. Curr Opin Plant Biol2014, 21:112-119.

7. Whenham R: Plant growth regulators and virus infection: a critical review. Plant Growth Regul1982, 1:37-59.

8. Jameson PE, Clarke SF: Hormone-virus interactions in plants. Crit RevPlant Sci2002, 21:205-228.

9. Kazan K, Manners JM: Linking development to defense: auxin in plant-pathogen interactions. Trends Plant Sci2009, 14:373-382. 
10. Padmanabhan MS, Shiferaw H, Culver JN: The Tobacco mosaic virus replicase protein disrupts the localization and function of interacting Aux/IAA proteins. Mol Plant Microbe Interact2006, 19:864-873.

11. Padmanabhan MS, Gorepoker SP, Golem S, Shiferaw H, Culver JN: Interaction of the tobacco mosaic virus replicase protein with the Aux/IAA protein PAPI/IAA26 is associated with disease development. $J$ Virol2005, 79:2549-2558.

12. Wang R, Estelle M: Diversity and specificity: auxin perception and signaling through the TIR1/AFB pathway. Curr Opin Plant Biol2014, 21:51-58.

13. Kasschau KD, Xie Z, Allen E, Llave C, Chapman EJ, Krizan KA, Carrington JC: P1/HCPro, a viral suppressor of RNA silencing, interferes with Arabidopsis development and miRNA function. Dev Cell2003, 4:205-217.

14. Zhu S, Gao F, Cao X, Chen M, Ye G, Wei C, Li Y: The rice dwarf virus P2 protein interacts with ent-kaurene oxidases in vivo, leading to reduced biosynthesis of gibberellins and rice dwarf symptoms. Plant Physiol 2005, 139:1935-1945.

15. Helliwell CA, Poole A, Peacock WJ, Dennis ES: Arabidopsis ent-kaurene oxidase catalyzes three steps of gibberellin biosynthesis. Plant Physiol1999, 119:507-510.

16. Itoh H, Tatsumi T, Sakamoto T, Otomo K, Toyomasu T, Kitano H, Ashikari M, Ichihara S, Matsuoka M: A rice semi-dwarf gene, Tan-Ginbozu (D35), encodes the gibberellin biosynthesis enzyme, ent-kaurene oxidase. Plant Mol Biol2004, 54:533-547.

17. Love AJ, Laird J, Holt J, Hamilton AJ, Sadanandom A, Milner JJ: Cauliflower mosaic virus protein P6 is a suppressor of RNA silencing. J Gen Virol2007, 88:3439-3444. 
18. Harries PA, Palanichelvam K, Yu W, Schoelz JE, Nelson RS: The cauliflower mosaic virus protein $\mathbf{P 6}$ forms motile inclusions that traffic along actin microfilaments and stabilize microtubules. Plant Physiol2009, 149:1005-1016.

19. Cecchini E, Gong Z, Geri C, Covey SN, Milner JJ: Transgenic Arabidopsis lines expressing gene VI from cauliflower mosaic virus variants exhibit a range of symptom-like phenotypes and accumulate inclusion bodies. Mol Plant Microbe Interact1997, 10:1094-1101.

20. Geri C, Cecchini E, Giannakou ME, Covey SN, Milner JJ: Altered patterns of gene expression in Arabidopsis elicited by cauliflower mosaic virus (CaMV) infection and by a CaMV gene VI transgene. Mol Plant Microbe Interact1999, 12:377-384.

21. Geri C, Love AJ, Cecchini E, Barrett SJ, Laird J, Covey SN, Milner JJ: Arabidopsis mutants that suppress the phenotype induced by transgene-mediated expression of cauliflower mosaic virus (CaMV) gene VI are less susceptible to CaMV-infection and show reduced ethylene sensitivity. Plant Mol Biol2004, 56:111-124.

22. Jones JD, Dangl JL: The plant immune system. Nature 2006, 444:323-329.

23. Vlot AC, Dempsey DMA, Klessig DF: Salicylic acid, a multifaceted hormone to combat disease. Annu Rev Phytopathol2009, 47:177-206.

24. Fu ZQ, Dong X: Systemic acquired resistance: turning local infection into global defense. Annu Rev Plant Biol2013, 64:839-863.

25. Boatwright JL, Pajerowska- Mukhtar K: Salicylic acid: an old hormone up to new tricks. Mol Plant Pathol2013, 14:623-634.

26. Torres MA, Jones JD, Dangl JL: Reactive oxygen species signaling in response to pathogens. Plant Physiol2006, 141:373-378. 
*27. Wang X, Sager R, Cui W, Zhang C, Lu H, Lee J-Y: Salicylic acid regulates plasmodesmata closure during innate immune responses in Arabidopsis. Plant Cell2013, 25:2315-2329.

This study connects the salicylic acid pathway with callose deposition at the plasmodesmata and the regulation of plasmodesmata permeability during a pathogen defense response.

28. Glazebrook J: Contrasting mechanisms of defense against biotrophic and necrotrophic pathogens. Annu Rev Phytopathol2005, 43:205-227.

29. Howe GA, Jander G: Plant immunity to insect herbivores. Annu Rev Plant Biol2008, 59:41-66.

30. Pieterse CM, Van der Does D, Zamioudis C, Leon-Reyes A, Van Wees SC: Hormonal modulation of plant immunity. Annu Rev Cell Dev Biol2012, 28:489-521.

31. Mur LA, Kenton P, Atzorn R, Miersch O, Wasternack C: The outcomes of concentrationspecific interactions between salicylate and jasmonate signaling include synergy, antagonism, and oxidative stress leading to cell death. Plant Physiol2006, 140:249262.

32. Schenk PM, Kazan K, Wilson I, Anderson JP, Richmond T, Somerville SC, Manners JM: Coordinated plant defense responses in Arabidopsis revealed by microarray analysis. Proc Natl Acad Sci USA2000, 97:11655-11660.

33. Van Wees SC, De Swart EA, Van Pelt JA, Van Loon LC, Pieterse CM: Enhancement of induced disease resistance by simultaneous activation of salicylate-and jasmonatedependent defense pathways in Arabidopsis thaliana. Proc Natl Acad Sci USA2000, 97:8711-8716. 
34. Delaney TP, Uknes S, Vernooij B, Friedrich L: A central role of salicylic acid in plant disease resistance. Science 1994, 266:1247.

35. Takahashi H, Kanayama Y, Zheng MS, Kusano T, Hase S, Ikegami M, Shah J: Antagonistic interactions between the SA and JA signaling pathways in Arabidopsis modulate expression of defense genes and gene-for-gene resistance to cucumber mosaic virus. Plant Cell Physiol2004, 45:803-809.

36. Sánchez G, Gerhardt N, Siciliano F, Vojnov A, Malcuit I, Marano MR: Salicylic acid is involved in the $\mathrm{Nb}$-mediated defense responses to Potato virus $\mathrm{X}$ in Solanum tuberosum. Mol Plant Microbe Interact2010, 23:394-405.

37. Jovel J, Walker M, Sanfaçon H: Salicylic acid-dependent restriction of Tomato ringspot virus spread in tobacco is accompanied by a hypersensitive response, local RNA silencing, and moderate systemic resistance. Mol Plant Microbe Interact2011, 24:706718.

38. Naylor M, Murphy AM, Berry JO, Carr JP: Salicylic acid can induce resistance to plant virus movement. Mol Plant Microbe Interact1998, 11:860-868.

39. Baebler Š, Witek K, Petek M, Stare K, Tušek-Žnidarič M, Pompe-Novak M, Renaut J, Szajko K, Strzelczyk-Żyta D, Marczewski W: Salicylic acid is an indispensable component of the Ny-1 resistance-gene-mediated response against Potato virus $\mathrm{Y}$ infection in potato. $J$ Exp Bot2014, 65:1095-1109.

40. Wang X, Goregaoker SP, Culver JN: Interaction of the Tobacco mosaic virus replicase protein with a NAC domain transcription factor is associated with the suppression of systemic host defenses. J Virol2009, 83:9720-9730. 
41. Laird J, McInally C, Carr C, Doddiah S, Yates G, Chrysanthou E, Khattab A, Love AJ, Geri C, Sadanandom A: Identification of the domains of cauliflower mosaic virus protein P6 responsible for suppression of RNA silencing and salicylic acid signalling. J Gen Virol2013, 94:2777-2789.

**42. Love AJ, Geri C, Laird J, Carr C, Yun B-W, Loake GJ, Tada Y, Sadanandom A, Milner JJ: Cauliflower mosaic virus protein P6 inhibits signaling responses to salicylic acid and regulates innate immunity. PLoS One 2012, 7:e47535.

This study describes a novel role for P6 as a pathogenicity effector that modifies NPR1, a key regulator of salicylic acid and jasmonic acid dependent signaling. In the presence of P6, an inactive form of NPR1 is mislocalized to the nucleus resulting in suppression of salicylic acid mediated defense responses and enhancement of jasmonic acid mediated defense responses.

**43. Rodriguez MC, Conti G, Zavallo D, Manacorda CA, Asurmendi S: TMV-Cg Coat Protein stabilizes DELLA proteins and in turn negatively modulates salicylic acidmediated defense pathway during Arabidopsis thaliana viral infection. BMC Plant Biol2014, 14:210.

This study demonstrates DELLA proteins, which are central players in phytohormone cross-talk, are stabilized during viral infection by TMV-Cg CP. As a result salicylic acid-mediated defense responses are reduced, suggesting stabilizing DELLA proteins is a novel mechanism to negatively modulate antiviral defense responses. 
44. Navarro L, Bari R, Achard P, Lisón P, Nemri A, Harberd NP, Jones JD: DELLAs control plant immune responses by modulating the balance of jasmonic acid and salicylic acid signaling. Curr Biol2008, 18:650-655.

45. Oka K, Kobayashi M, Mitsuhara I, Seo S: Jasmonic acid plays a negative role in resistance to Tobacco mosaic virus in tobacco. Plant Cell Physiol2013:pct137.

46. Dhondt S, Geoffroy P, Stelmach BA, Legrand M, Heitz T: Soluble phospholipase A2 activity is induced before oxylipin accumulation in tobacco mosaic virus- infected tobacco leaves and is contributed by patatin- like enzymes. Plant J2000, 23:431-440.

47. Kovač M, Müller A, Jarh DM, Milavec M, Düchting P, Ravnikar M: Multiple hormone analysis indicates involvement of jasmonate signalling in the early defence of potato to potato virus YNTN. Biol Plant2009, 53:195-199.

*48. Lozano-Durán R, Rosas-Díaz T, Gusmaroli G, Luna AP, Taconnat L, Deng XW, Bejarano ER: Geminiviruses subvert ubiquitination by altering CSN-mediated derubylation of SCF E3 ligase complexes and inhibit jasmonate signaling in Arabidopsis thaliana. Plant Cell2011, 23:1014-1032.

This publication describes a novel strategy used by DNA viruses to redirect ubiquitination by interfering with the activity of the COP9 signalosome complex. The result is suppression of the jasmonate response which may be crucial for geminivirus infection.

49. Zhang JF, Yuan LJ, Shao Y, Du W, Yan DW, Lu YT: The disturbance of small RNA pathways enhanced abscisic acid response and multiple stress responses in Arabidopsis. Plant Cell Environ2008, 31:562-574. 
50. Earley K, Smith M, Weber R, Gregory B, Poethig R: Research An endogenous F-box protein regulates ARGONAUTE1 in Arabidopsis thaliana. Silence 2010, 1:15.

51. Li W, Cui X, Meng Z, Huang X, Xie Q, Wu H, Jin H, Zhang D, Liang W: Transcriptional regulation of Arabidopsis MIR168a and argonaute1 homeostasis in abscisic acid and abiotic stress responses. Plant Physiol2012, 158:1279-1292.

52. Yu D, Fan B, MacFarlane SA, Chen Z: Analysis of the involvement of an inducible Arabidopsis RNA-dependent RNA polymerase in antiviral defense. Mol Plant Microbe Interact2003, 16:206-216.

53. Alamillo JM, Saénz P, García JA: Salicylic acid- mediated and RNA- silencing defense mechanisms cooperate in the restriction of systemic spread of plum pox virus in tobacco. Plant J2006, 48:217-227.

54. Campos L, Granell P, Tárraga S, López-Gresa P, Conejero V, Bellés JM, Rodrigo I, Lisón P: Salicylic acid and gentisic acid induce RNA silencing-related genes and plant resistance to RNA pathogens. Plant Physiol Biochem2014, 77:35-43.

55. Hunter LJ, Westwood JH, Heath G, Macaulay K, Smith AG, MacFarlane SA, Palukaitis P, Carr JP: Regulation of RNA-dependent RNA polymerase 1 and isochorismate synthase gene expression in Arabidopsis. PLoS One 2013, 8:e66530.

**56. Tian M, Sasvari Z, Gonzalez PA, Friso G, Rowland E, Liu X-M, van Wijk KJ, Nagy PD, Klessig DF: Salicylic acid inhibits the replication of Tomato Bushy Stunt Virus by directly targeting a host component in the replication complex. Mol Plant Microbe Interact2015, 28:379-386.

This work describes a novel mechanism for salicylic acid to modulate virus biology by competitively binding to a host protein required for viral replication. 
2 57. Huang T-S, Nagy PD: Direct inhibition of tombusvirus plus-strand RNA synthesis by a dominant negative mutant of a host metabolic enzyme, glyceraldehyde-3-phosphate dehydrogenase, in yeast and plants. $J$ Virol2011, 85:9090-9102.

58. Wang RY-L, Nagy PD: Tomato bushy stunt virus co-opts the RNA-binding function of a host metabolic enzyme for viral genomic RNA synthesis. Cell Host Microbe2008, 3:178-187.

59. Alazem M, Lin K-Y, Lin N-S: The abscisic acid pathway has multifaceted effects on the accumulation of Bamboo mosaic virus. Mol Plant Microbe Interact2014, 27:177-189.

60. Rezzonico E, Flury N, Meins F, Beffa R: Transcriptional down-regulation by abscisic acid of pathogenesis-related $\beta$-1, 3-glucanase genes in tobacco cell cultures. Plant Physiol1998, 117:585-592.

61. Zavaliev R, Ueki S, Epel BL, Citovsky V: Biology of callose (及-1, 3-glucan) turnover at plasmodesmata. Protoplasma 2011, 248:117-130.

62. Flors V, Ton J, Jakab G, Mauch- Mani B: Abscisic acid and callose: team players in defence against pathogens?J Phytopathol2005, 153:377-383.

63. Beffa RS, Hofer R-M, Thomas M, Meins F: Decreased Susceptibility to Viral Disease of [beta]-1, 3-Glucanase-Deficient Plants Generated by Antisense Transformation. Plant Cell1996, 8:1001-1011.

64. Iglesias VA, Meins F: Movement of plant viruses is delayed in a $\boldsymbol{\beta}-\mathbf{1}$, 3- glucanase- deficient mutant showing a reduced plasmodesmatal size exclusion limit and enhanced callose deposition. Plant J2000, 21:157-166. 
65. Whenham R: Abscisic acid metabolism in tomato plants infected with tobacco mosaic virus: relationships with growth, symptoms and the Tm-1 gene for TMV resistance. Physiol MolPlant Pathol1989, 34:215-226.

66. Iriti M, Faoro F: Abscisic acid is involved in chitosan-induced resistance to tobacco necrosis virus (TNV). Plant Physiol Biochem2008, 46:1106-1111.

67. Lee J-Y, Wang X, Cui W, Sager R, Modla S, Czymmek K, Zybaliov B, van Wijk K, Zhang C, Lu H: A plasmodesmata-localized protein mediates crosstalk between cell-to-cell communication and innate immunity in Arabidopsis. Plant Cell2011, 23:3353-3373.

68. Chivasa S, Murphy AM, Naylor M, Carr JP: Salicylic acid interferes with tobacco mosaic virus replication via a novel salicylhydroxamic acid-sensitive mechanism. Plant Cell1997, 9:547-557.

69. Abe H, Tomitaka Y, Shimoda T, Seo S, Sakurai T, Kugimiya S, Tsuda S, Kobayashi M: Antagonistic plant defense system regulated by phytohormones assists interactions among vector insect, thrips and a tospovirus. Plant Cell Physiol2012, 53:204-212.

70. Lewsey MG, Murphy AM, MacLean D, Dalchau N, Westwood JH, Macaulay K, Bennett MH, Moulin M, Hanke DE, Powell G: Disruption of two defensive signaling pathways by a viral RNA silencing suppressor. Mol Plant Microbe Interact2010, 23:835-845.

71. Ziebell H, Murphy AM, Groen SC, Tungadi T, Westwood JH, Lewsey MG, Moulin M, Kleczkowski A, Smith AG, Stevens M: Cucumber mosaic virus and its 2b RNA silencing suppressor modify plant-aphid interactions in tobacco. Sci Rep2011, 1:187.

*72. Casteel C, De Alwis M, Bak A, Dong H, Steven A, Jander G: Disruption of ethylene responses by Turnip mosaic virus mediates suppression of plant defense against the aphid vector, Myzus persicae. Plant Physiol2015, 169:209-218. 
1 This work shows that disruption of ethylene responses in plants is one function of the highly

2 conserved Potyvirus protein, NIa-Pro. Changes in ethylene responses may mediate vector-plant

3 interactions and be an important mechanism for increased insect transmission of this important

4 group of viruses.

6 Figure 1. Virus and phytohormone pathway interactions.Phytohormones shown in blue generally

7 have positive effects on plant defense against viruses, while phytohormones shown in red

8 generally have negative effects. SA and JA / ET are the phytohormones primarily involved in

9 defense responses, while Aux, GA, CK, BR and ABA also contribute to defense but play key

10 roles in plant development and physiological processes [2-4]. The ABA and JA pathways have

11 positive effects on defense against herbivorous insects that can act as viral vectors [29]. JA also

12 promotes defense against Geminiviruses[48]. Viruses boxed in red inhibit SA mediated defense

13 responses either through inhibition of the GA and SA pathways[14,40,42,43] or through

14 activation of the antagonistic phytohormone Aux [11,13]. Viruses boxed in blue inhibit JA and

15 ABA mediated defense responses against their insect vector either directly [71] or through

16 activation of the SA or ET pathways which can both be antagonistic to ABA [69,72].

17 Geminiviruses boxed in green inhibit JA signaling [48]. SA and ABA are also linked to the 18 general virus defense mechanism of RNA silencing [51,54]. SA, salicylic acid; JA, jasmonic 19 acid; ET, ethylene; Aux, auxin; GA, gibberellins; CK, cytokinins; BR, brassinosteroids; ABA, 20 abscisic acid; TMV, Tobacco mosaic virus; RDV, Rice dwarf virus; CaMV, Cauliflower mosaic 21 virus; TSWV,Tomato spotted wilt virus; TuMV,Turnip mosaic virus; CMV, Cucumber mosaic 22 virus. 
Table 1.

Specific virus-host interactions that impact phytohormone pathways.

\begin{tabular}{|c|c|c|c|c|c|}
\hline $\begin{array}{l}\text { Phytohormone } \\
\text { Pathway }\end{array}$ & Virus & $\begin{array}{l}\text { Viral } \\
\text { Protein } \\
\end{array}$ & $\begin{array}{l}\text { Host } \\
\text { Component }\end{array}$ & Result & Reference \\
\hline \multirow[t]{2}{*}{ Increases Aux signaling } & TMV & $126 \mathrm{kDa}$ & $\begin{array}{l}\text { IAA26 } \\
\text { IAA27 } \\
\text { IAA18 }\end{array}$ & $\begin{array}{l}\text { Enhanced phloem } \\
\text { loading and viral } \\
\text { systemic movement, } \\
\text { symptom development }\end{array}$ & $\begin{array}{l}{[10,11]} \\
\text { Unpublished } \\
\text { Work }\end{array}$ \\
\hline & TuMV & HC-Pro & $\begin{array}{l}\text { miR167 } \\
\text { (targets } \\
\text { ARF8) }\end{array}$ & $\begin{array}{l}\text { Symptom } \\
\text { development }\end{array}$ & [13] \\
\hline \multirow[t]{2}{*}{ Alters ET responses } & TuMV & NIA-Pro & unknown & $\begin{array}{l}\text { Suppresses callose } \\
\text { formation to promote } \\
\text { transmission by insect } \\
\text { vector }\end{array}$ & [72] \\
\hline & CaMV & P6 & unknown & $\begin{array}{l}\text { Symptom } \\
\text { development }\end{array}$ & {$[20,21]$} \\
\hline Inhibits GA synthesis & RDV & P2 & $\begin{array}{l}\text { ent-Kaurene } \\
\text { oxidase }\end{array}$ & $\begin{array}{l}\text { Enhanced } \\
\text { susceptibility, } \\
\text { symptom development }\end{array}$ & {$[14]$} \\
\hline $\begin{array}{l}\text { Inhibits GA signaling, } \\
\text { inhibits SA mediated } \\
\text { defense }\end{array}$ & TMV-Cg & $\mathrm{CgCP}$ & $\begin{array}{l}\text { DELLA } \\
\text { proteins }\end{array}$ & $\begin{array}{l}\text { Enhanced viral } \\
\text { accumulation }\end{array}$ & [43] \\
\hline $\begin{array}{l}\text { Reduces SA defense } \\
\text { responses }\end{array}$ & TMV & $126 \mathrm{kDa}$ & ATAF2 & $\begin{array}{l}\text { Enhanced viral } \\
\text { accumulation }\end{array}$ & {$[40]$} \\
\hline $\begin{array}{l}\text { Inhibits SA signaling, } \\
\text { enhances JA signaling }\end{array}$ & CaMV & P6 & NPR1 & $\begin{array}{l}\text { Enhanced } \\
\text { susceptibility }\end{array}$ & {$[42]$} \\
\hline $\begin{array}{l}\text { Increases SA signaling, } \\
\text { Inhibits JA signaling }\end{array}$ & TSWV & unknown & unknown & $\begin{array}{l}\text { Promotes insect } \\
\text { vector feeding }\end{array}$ & [69] \\
\hline Inhibits JA signaling & Geminivirus & $\mathrm{C} 2$ & CSN5 & $\begin{array}{l}\text { Enhanced viral } \\
\text { replication }\end{array}$ & [48] \\
\hline Decreases JA signaling & CMV & $2 b$ & unknown & $\begin{array}{l}\text { Promotes insect } \\
\text { vector feeding }\end{array}$ & [71] \\
\hline
\end{tabular}




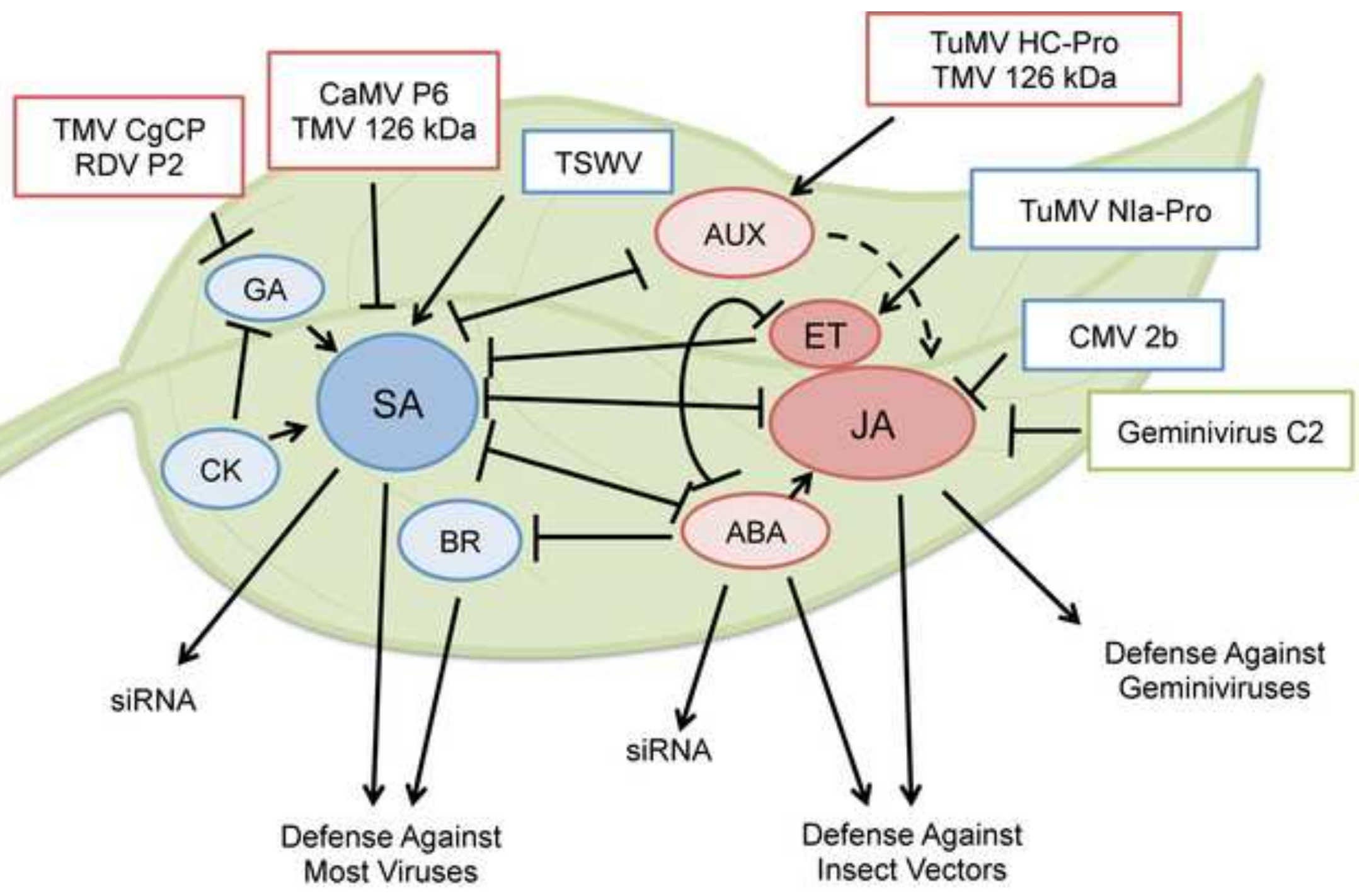

